\title{
Commentary: Epidemiology of Antibody-Positive Autoimmune Encephalitis in Southwest China: A Multicenter Study
}

\author{
Yanbing Zhou, Zirui Meng and Binwu Ying* \\ Department of Laboratory Medicine, West China Hospital, Sichuan University, Chengdu, China
}

Keywords: autoimmune encephalitis, epidemiology, neuronal autoantibodies, thyroid peroxidase antibodies, glasgow outcome scale, modified rankin scale, response to immunotherapy in epilepsy and encephalopathy score

\section{OPEN ACCESS}

Edited by:

Betty Diamond,

Feinstein Institute for Medical Research,

United States

Reviewed by:

Eoin Flanagan,

Mayo Clinic, United States

${ }^{*}$ Correspondence:

Binwu Ying

binwuying@126.com

Specialty section:

This article was submitted to

Autoimmune and Autoinflammatory

Disorders,

a section of the journal

Frontiers in Immunology

Received: 17 January 2020

Accepted: 21 July 2020

Published: 28 August 2020

Citation:

Zhou Y, Meng Z and Ying B (2020)

Commentary: Epidemiology of

Antibody-Positive Autoimmune

Encephalitis in Southwest China: A

Multicenter Study.

Front. Immunol. 11:1976.

doi: 10.3389/fimmu.2020.01976

\section{A Commentary on}

Epidemiology of Antibody-Positive Autoimmune Encephalitis in Southwest China: A Multicenter Study

by Gu, Y., Zhong, M., He, L., Li, W., Huang, Y., Liu, J., et al. (2019). Front. Immunol. 10:2611. doi: 10.3389/fimmu.2019.02611

Recently, Gu et al. reported an epidemiological survey about autoimmune encephalitis (AE) in southwestern China, involving six large general hospitals in Chongqing (1). Their study revealed the underlying relationship between several factors and disease severity (1). Although there have been no large-scale epidemiological investigations of $\mathrm{AE}$ in China prior to this report (1), the conclusions of this research would have been more reliable had the following concerns been addressed.

First, the limited scale of this epidemiological investigation merits discussion. The detailed epidemiological features of $\mathrm{AE}$ in southwestern China were presented in this multicenter study involving six large general hospitals in the Chongqing area. These six general hospitals in Chongqing were limited to reflect the epidemiological features of AE patients in the southwestern region of China.

Moreover, it is noteworthy that researchers excluded patients with thyroid disease (1). However, some patients with Hashimoto's encephalopathy (HE), which is an important cause of autoimmune encephalopathy, may be neglected. High titers of thyroid peroxidase antibodies (TPO-Ab) is generally detected in HE patients (2). And morbidity of HE is estimated to be 2.1/100,000 in adults (3). Additionally, TPO-Ab detection was recommended to be tested in the systematic diagnosis per the clinical diagnosis criteria of AE published in 2016 (4). Therefore, it is quite likely to miss potential patients with AE by excluding patients with thyroid disease.

Also, the methods of antibody detection in the publication need to be further elaborated. According to the 2016 clinical diagnosis criteria of AE, antibody detection in definite AE-like encephalitis with anti-NMDA receptor antibody-positive status should include cerebrospinal fluid (CSF) testing with cell-based assay (CBA) and with confirmatory tests like tissue immunohistochemistry based on animals' brain tissue (4). The tissue immunohistochemistry has been widely used by some studies of $\mathrm{AE}(5-7)$. In the author's study, only CBA based on indirect immunofluorescence (IIF) assay was performed to analyze both the CSF and serum of each patient (1). Thus, owing to significant inter-operator variability in CBA performed by different technologists, the standard of determining antibody titers should be explained in detail. 
Further, the assessment scale of disease severity in research needs more discussion. The authors have used the Glasgow Outcome Scale (GOS) to evaluate factors that may be associated with disease prognosis (1). The GOS was initially designed to predict the outcome after brain injury-like traumas (8-11). However, some researchers have indicated that GOS has some deficiencies because it cannot detect minor brain damage (12). Therefore, we suggest that it would be better if the researchers could combine GOS with some scales that are more appropriate to predict the outcome of AE. Although no specific scale has been designed yet to predict AE prognosis (13), some studies have supported the use of the modified Rankin Scale (mRS), which is more frequently used in the evaluation of AE prognosis (14-17). Another scale called the Response to Immunotherapy in Epilepsy and Encephalopathy score (RITE2 score) has also been used to evaluate and manage autoimmune-epilepsy $(18,19)$.

In summary, this is a meaningful report providing epidemiological data about the antibody distribution in $\mathrm{AE}$

\section{REFERENCES}

1. Gu Y, Zhong M, He L, Li W, Huang Y, Liu J, et al. Epidemiology of antibodypositive autoimmune encephalitis in Southwest China: a multicenter study. Front Immunol. (2019) 10:2611. doi: 10.3389/fimmu.2019.02611

2. Li J, Li F. Hashimoto's encephalopathy and seizure disorders. Front Neurol. (2019) 10:440. doi: 10.3389/fneur.2019.00440

3. Ferracci F, Moretto G, Candeago RM, Cimini N, Conte F, Gentile $\mathrm{M}$, et al. Antithyroid antibodies in the CSF: their role in the pathogenesis of Hashimoto's encephalopathy. Neurology. (2003) 60:712-4. doi: 10.1212/01.WNL.0000048660.71390.C6

4. Graus F, Titulaer MJ, Balu R, Benseler S, Bien CG, Cellucci T, et al. A clinical approach to diagnosis of autoimmune encephalitis. Lancet Neurol. (2016) 15:391-404. doi: 10.1016/S1474-4422(15)00401-9

5. Ricken G, Schwaiger C, De Simoni D, Pichler V, Lang J, Glatter S, et al. Detection methods for autoantibodies in suspected autoimmune encephalitis. Front Neurol. (2018) 9:841. doi: 10.3389/fneur.2018. 00841

6. Liu $\mathrm{T}$, Chen B, Yang $\mathrm{H}$, Huang J, Liu S, Yang X, et al. Screening for autoantibodies in inflammatory neurological syndrome using fluorescence pattern in a tissue-based assay: cerebrospinal fluid findings from 793 patients. Multiple Scler Relat Disord. (2019) 28:177-83. doi: 10.1016/j.msard.2018.12.036

7. Bien CI, Nehls F, Kollmar R, Weis M, Steinke W, Woermann F, et al. Identification of adenylate kinase 5 antibodies during routine diagnostics in a tissue-based assay: Three new cases and a review of the literature. $J$ Neuroimmunol. (2019) 334:576975. doi: 10.1016/j.jneuroim.2019.576975

8. McMillan T, Wilson L, Ponsford J, Levin H, Teasdale G, Bond M. The Glasgow Outcome Scale - 40 years of application and refinement. Nat Rev Neurol. (2016) 12:477-85. doi: 10.1038/nrneurol.2016.89

9. Jennett B, Teasdale G, Galbraith S, Pickard J, Grant H, Braakman R, et al. Severe head injuries in three countries. J Neurol Neurosurg Psychiatry. (1977) 40:291-8. doi: 10.1136/jnnp.40.3.291

10. Bates D, Caronna JJ, Cartlidge NE, Knill-Jones RP, Levy DE, Shaw DA, et al. A prospective study of nontraumatic coma: methods and results in 310 patients. Ann Neurol. (1977) 2:211-20. doi: 10.1002/ana.410020306

11. Langfitt TW. Measuring the outcome from head injuries. J Neurosurg. (1978) 48:673-8. doi: $10.3171 /$ jns. 1978.48 .5 .0673 in the Chongqing area, along with revealing the factors associated with poor prognosis of AE. Despite some of the above-mentioned concerns, this study would be helpful to researchers and clinicians alike to gain more insight into AE.

\section{AUTHOR CONTRIBUTIONS}

All authors listed have made a substantial, direct and intellectual contribution to the work, and approved it for publication.

\section{ACKNOWLEDGMENTS}

I would like to show my deepest gratitude to my supervisor, BY, who has been supporting my commentary. I shall extend my thanks to Mr. Wang, Miss. Si, Miss Guo as well as Miss. Meng, who have been helping me to develop the fundamental and essential academic competence and essential academic competence.

12. Beers SR, Wisniewski SR, Garcia-Filion P, Tian Y, Hahner T, Berger RP, et al. Validity of a pediatric version of the Glasgow Outcome Scale-Extended. J Neurotrauma. (2012) 29:1126-39. doi: 10.1089/neu.2011.2272

13. Lim J-A, Lee S-T, Moon J, Jun J-S, Kim T-J, Shin Y-W, et al. Development of the clinical assessment scale in autoimmune encephalitis. Ann Neurol. (2019) 85:352-8. doi: 10.1002/ana.25421

14. Huang X, Fan C, Wu J, Ye J, Zhan S, Song H, et al. Clinical analysis on anti$\mathrm{N}$-methyl-D-aspartate receptor encephalitis cases: Chinese experience. Int J Clin Exp Med. (2015) 8:18927-35. Available online at: http://europepmc.org/ article/PMC/4694417

15. Gresa-Arribas N, Titulaer MJ, Torrents A, Aguilar E, McCracken L, Leypoldt F, et al. Antibody titres at diagnosis and during follow-up of anti-NMDA receptor encephalitis: a retrospective study. Lancet Neurol. (2014) 13:16777. doi: 10.1016/S1474-4422(13)70282-5

16. Titulaer MJ, McCracken L, Gabilondo I, Armangué T, Glaser C, Iizuka T, et al. Treatment and prognostic factors for long-term outcome in patients with antiNMDA receptor encephalitis: an observational cohort study. Lancet Neurol. (2013) 12:157-65. doi: 10.1016/S1474-4422(12)70310-1

17. Lee W-J, Lee S-T, Byun J-I, Sunwoo J-S, Kim T-J, Lim J-A, et al. Rituximab treatment for autoimmune limbic encephalitis in an institutional cohort. Neurology. (2016) 86:1683-91. doi: 10.1212/WNL.0000000000002635

18. Husari KS, Dubey D. Autoimmune epilepsy. Neurotherapeutics. (2019) 16:685-702. doi: 10.1007/s13311-019-00750-3

19. Dubey D, Kothapalli N, McKeon A, Flanagan EP, Lennon VA, Klein CJ, et al. Predictors of neural-specific autoantibodies and immunotherapy response in patients with cognitive dysfunction. J Neuroimmunol. (2018) 323:6272. doi: 10.1016/j.jneuroim.2018.07.009

Conflict of Interest: The authors declare that the research was conducted in the absence of any commercial or financial relationships that could be construed as a potential conflict of interest.

Copyright (c) 2020 Zhou, Meng and Ying. This is an open-access article distributed under the terms of the Creative Commons Attribution License (CC BY). The use, distribution or reproduction in other forums is permitted, provided the original author(s) and the copyright owner(s) are credited and that the original publication in this journal is cited, in accordance with accepted academic practice. No use, distribution or reproduction is permitted which does not comply with these terms. 